Article

\title{
The Influence of Moisture Content and Temperature on the Long-Term Storage Stability of Freeze-Dried High Concentration Immunoglobulin G (IgG)
}

\author{
Arnold Duralliu ${ }^{1}$, Paul Matejtschuk ${ }^{2}$, Paul Stickings ${ }^{3}$, Laura Hassall ${ }^{3}$, Robert Tierney ${ }^{3}$ and \\ Daryl R. Williams ${ }^{1, *}$ \\ 1 Surfaces and Particle Engineering Laboratory, Department of Chemical Engineering, Imperial College \\ London, SW7 2AZ, UK; a.duralliu15@imperial.ac.uk \\ 2 Standardisation Science, National Institute for Biological Standards and Control, Blanche Lane, \\ South Mimms, Potters Bar, Hertfordshire, EN6 3QG, UK; Paul.Matejtschuk@nibsc.org \\ 3 Bacteriology Division, National Institute for Biological Standards and Control, Blanche Lane, South Mimms, \\ Potters Bar, Hertfordshire, EN6 3QG, UK; Paul.Stickings@nibsc.org (P.S.); Laura.Hassall@nibsc.org (L.H.); \\ Robert.Tierney@nibsc.org (R.T.) \\ * Correspondence: d.r.williams@imperial.ac.uk; Tel.: +44-207-594-5611
}

Received: 20 February 2020; Accepted: 24 March 2020; Published: 27 March 2020

\begin{abstract}
High protein concentration products for targeted therapeutic use are often freeze-dried to enhance stability. The long-term storage stability of freeze-dried (FD) plasma-derived Immunoglobulin $\mathrm{G}(\mathrm{IgG})$ from moderate to high concentrations $(10-200 \mathrm{mg} / \mathrm{mL})$ was assessed. Monomer content, binding activity and reconstitution times were evaluated over a 12-month period under accelerated and real-term storage conditions. In the first case study it was shown that FD IgG from 10 to $200 \mathrm{mg} / \mathrm{mL}$ had minimal monomer/activity losses at up to ambient temperature after 12 months of storage. However, at $45{ }^{\circ} \mathrm{C}$ the sucrose-to-protein ratio played a significant impact on $\operatorname{IgG}$ stability above $50 \mathrm{mg} / \mathrm{mL}$. All IgG concentrations witnessed moisture ingress over a 12-month period. The impact of moisture ingress from environmental exposure (between $0.1 \%$ and $5 \% w / w$ moisture) for $\operatorname{IgG} 50 \mathrm{mg} / \mathrm{mL}$ was assessed, being generated by exposing low moisture batches to an atmospheric environment for fixed time periods. Results showed that at $-20^{\circ} \mathrm{C}$ and $20^{\circ} \mathrm{C}$ there was no significant difference in terms of monomer or antigen-binding activity losses over 6 months. However, at $45^{\circ} \mathrm{C}$, there were losses in monomer content, seemingly worse for higher moisture content samples although model binding activity indicated no losses. Finally, the difference between a low moisture product $(0.1-1 \% w / w)$ and a moderately high moisture $(3 \% w / w)$ product generated by alternative freeze-drying cycles, both stoppered under low oxygen headspace conditions, was evaluated. Results showed that at $-20^{\circ} \mathrm{C}$ and $20^{\circ} \mathrm{C}$ there was no difference in terms of binding activity or monomer content. However, at $45^{\circ} \mathrm{C}$, the low moisture samples had greater monomer and binding activity losses than samples from the highest moisture cycle batch, indicating that over-drying can be an issue.
\end{abstract}

Keywords: freeze-drying; Immunoglobulin G; concentration; stability; monomer; binding activity; moisture; reconstitution

\section{Introduction}

There is rising demand in the biopharmaceutical industry for increasingly high concentrations of therapeutic proteins, such as monoclonal antibodies (mAbs). However, with this requirement there comes a host of challenges, including an increased instability, degradation and viscosity, as well as unwanted protein-protein interactions in the liquid state [1,2]. There is no precise standardized definition of what constitutes a "high concentration" protein formulation but generally it has been 
considered to fall between 50 and $150 \mathrm{mg} / \mathrm{mL}$ [3]. Freeze-drying (FD) is a common technique used to enhance shelf stability by delivering a product in a solid-state format. [4,5]. It consists of three stages: (1) Freezing (solidification), (2) primary drying (sublimation of frozen ice) and (3) secondary drying (desorption of bound water). Sugar-based excipients are usually added to these formulations to enhance the stability of the active pharmaceutical ingredient (API) during prolonged storage. Other studies have focused their investigations into the slow reconstitution times of high concentration protein formulations and ways to improve them [6,7]. However, in addition to the continuing development of higher protein concentration formulations in FD formats, there are challenges with regard to selecting the appropriate moisture content for long-term storage stability. Typically, after FD the resulting solid freeze-dried "cake" would be expected to have a low moisture content. For FD intravenous Immunoglobulin G formulations, the acceptable moisture contents would be at or below $3 \% w / w$ [8]. Plasma-derived immunoglobulin has long been used as a therapeutic product and intravenous immunoglobulin concentrations of $50-100 \mathrm{mg} / \mathrm{mL}$ are common $[9,10]$. Previous studies have also looked into the stability of mAbs with regard to higher moisture content ranges of between $1 \%$ and $8 \% w / w$; however, these studies focussed on the impact of the higher end of the moisture range. Breen et al. [11] was able to show that while increasing the moisture content up to $8 \%$ w/w might decrease chemical stability in FD rhuMAb, it might in fact actually increase the physical stability as long as storage was below the dry state glass transition $\left(\mathrm{T}_{\mathrm{g}}\right)$. The range of moisture content that is desirable in FD cakes has long been a matter of debate. Hsu et al. showed that an optimum moisture content range might exist, whereby both over and under drying could be detrimental to stability [12]. Long ago Greiff hypothesised that the relationship between moisture content and stability could correspond to a "bell shaped" distribution [13]. Alternatively, Pikal et al. noted that for FD Human Growth Hormone at $40{ }^{\circ} \mathrm{C}$, there was a linear relationship between moisture content and aggregation rather than a bell-shaped distribution [14]. Guidelines for use when developing stressing strategies for biotechnology products have been published [15] and industrial stressing conditions have also been reviewed [16,17]. During long-term storage, the sugar excipient used in the formulation, moisture content and temperature can all affect the physical and chemical stability of FD cakes. Plasma-derived IgG was chosen to be investigated here as a substitute model for a typical therapeutic mAbs because of its relative ease of availability at high concentrations. A comprehensive set of long-term case studies investigating the stability of FD IgG was assessed over a 6-12-month period. The monomer content, retention of anti-diphtheria/tetanus antibody titres and change in moisture content were evaluated under accelerated and real-time storage conditions $\left(-20{ }^{\circ} \mathrm{C}, \sim<5 \% \mathrm{RH} ; 20^{\circ} \mathrm{C}, \sim 40 \% \mathrm{RH}\right.$; and $45^{\circ} \mathrm{C}$, $\sim 10 \% \mathrm{RH}$, though the incubators used did not directly control the RH) to assess FD storage stability.

\section{Materials and Methods}

\subsection{Materials and Formulation Characterisation}

The bulk of the $50 \mathrm{mg} / \mathrm{mL} \operatorname{IgG}(2.2 \mathrm{~L})$ was obtained by dialysis from time-expired clinical grade standard product (NIBSC, Potters Bar, UK) and maintained sterile at $2-8{ }^{\circ} \mathrm{C}$. A quantity, $150 \mathrm{~mL}$, was dialysed into $1 \% \mathrm{w} / \mathrm{v}$ sucrose, $10 \mathrm{mM}$ citric acid adjusted at $\mathrm{pH} 6.6$ with $5 \mathrm{M} \mathrm{NaOH}$ and $0.01 \%$ Tween 20 against $3 \times 5$ L over $20 \mathrm{~h}$ using a Spectrapor $8 \mathrm{kDa}$ cut-off dialysis membrane (Sigma-Aldrich, Gillingham, UK). A portion from this bulk was diluted down to $10 \mathrm{mg} / \mathrm{mL}$. The remaining bulk pool was then ultrafiltered to get nominal target concentrations of 100 and $200 \mathrm{mg} / \mathrm{mL} \mathrm{IgG}$. All the preparations were then dialysed in dialysis membrane sacs against the citrate Tween 20 sucrose buffer. Target concentrations were achieved by diafiltration using the Vivaflow 200 crossflow system and with a 50 kDa PES (polyethyl sulfone) membrane cartridge (Sartorius Stedim Biotech, Gottingen, Germany). Concentrations were confirmed by OD $280 \mathrm{~nm}(\mathrm{E} 1 \%$ for IgG = 13.5 AU) using triplicate 1:100 dilutions measured with a UV spectrophotometer (Pharmacia Biotech, GE Healthcare, Little Chalfont, UK) blanked on sucrose citrate buffers. Average readings were $0.98 \pm 0.02 \%, 5.43 \% \pm 0.19 \%, 9.86 \% \pm 0.13 \%$ 
and $20.4 \% \pm 0.97 \% \mathrm{w} / \mathrm{v}$. These were approximated to $1 \%, 5 \%, 10 \%$ and $20 \% \mathrm{w} / \mathrm{v}$, which is equivalent to 10, 50, 100 and $200 \mathrm{mg} / \mathrm{mL}$, respectively.

\subsection{Modulated DSC}

Solid sample or liquid aliquots of IgG were loaded into large volume hermetically sealed pans (part number 900825.902 TA Instruments, Elstree, UK). Samples were evaluated on Q2000 DSC (TA Instruments) against an empty pan as reference. A heating ramp rate at $5^{\circ} \mathrm{C} / \mathrm{min}$ up to $200{ }^{\circ} \mathrm{C}$ was used. Instrument calibration was performed using an indium sample of known mass. Data analysis was performed using Universal Analysis Software (TA Instruments).

\subsection{Case Study 1: Freeze Drying of a High Concentration IgG}

A batch using a "low" moisture cycle run was included in all the IgG concentrations (10-200 mg/mL). Sample filling was completed with an automated multipette stream (Eppendorf, Stevenage, UK) into 5 mL volume screw capped vials $(41.5 \times 18$ mm i.d. Schott VC005, Adelphi Tubes, Haywards Heath, UK). The fill volume for all concentrations was $1 \mathrm{~mL}$. The vials were loaded onto the shelves of the Telstar LyoBeta 15 (Azbil-Telstar SpA, Terrassa, Spain). After the cycles had finished the vials were backfilled with dry $\mathrm{N}_{2}$ and were stoppered down with $14 \mathrm{~mm}$ diameter igloo halobutyl stoppers (Adelphi Group, Haywards Heath, UK). Afterwards the vials were screw-capped, labelled and stored at $-20^{\circ} \mathrm{C}, 20^{\circ} \mathrm{C}$ and $45^{\circ} \mathrm{C}$ until further testing.

\subsection{Case Study 2: Optimum Moisture Content of IgG}

A total of $50 \mathrm{mg} / \mathrm{mL}$ IgG was lyophilised with the same conditions and same "low" FD cycle as described in Section 3.2. After FD, samples were laboratory-stored at $20{ }^{\circ} \mathrm{C}$ (with a relative humidity of $57 \% \pm 2 \% \mathrm{RH}$, as measured with a TFH 620 Hygrothermometer (Ebro-Xylem, Ingoldstat, Germany). The stoppers were removed temporarily, and vials were exposed to the moisture in the external atmosphere for different time intervals $(0,30,90$ and $180 \mathrm{~min})$ to result in different moisture contents in the cakes. A total of 4 different moisture contents were prepared and an average confirmed using Karl Fisher titration in triplicate $(n=3)$.

\subsection{Case Study 3: Comparison of Low and High Moisture FD Cycles}

The "high" moisture cycle and "low" moisture cycle batches of FD IgG (50 mg/mL) were prepared to allow comparison between these two different cycles that induce moisture content as shown in Table 1. After FD cycles, samples were once again backfilled from vacuum with dry $\mathrm{N}_{2}$ and were stoppered down with $14 \mathrm{~mm}$ diameter igloo halobutyl stoppers (Adelphi Group, Haywards Heath, UK). Afterwards the vials were screw-capped, labelled and stored at $-20{ }^{\circ} \mathrm{C}, 20{ }^{\circ} \mathrm{C}$ and $45^{\circ} \mathrm{C}$ until further testing.

Table 1. Freeze drying cycle for IgG formulations.

\begin{tabular}{|c|c|c|c|c|c|c|c|c|}
\hline Cycle & $\begin{array}{c}\text { Freezing } \\
\text { Temperature } \\
\left({ }^{\circ} \mathrm{C}\right)\end{array}$ & $\begin{array}{c}\text { Freezing } \\
\text { Ramp Rate } \\
\left({ }^{\circ} \mathrm{C} / \mathrm{min}\right)\end{array}$ & $\begin{array}{l}\text { Freezing } \\
\text { Hold Time } \\
\text { (min) }\end{array}$ & $\begin{array}{c}\text { Primary } \\
\text { Drying } \\
\text { Temperature } \\
\left({ }^{\circ} \mathrm{C}\right)\end{array}$ & $\begin{array}{l}\text { Primary } \\
\text { Hold Time } \\
\text { (min) }\end{array}$ & $\begin{array}{c}\text { Secondary } \\
\text { Drying } \\
\text { Temperature } \\
\left({ }^{\circ} \mathrm{C}\right)\end{array}$ & $\begin{array}{c}\text { Secondary } \\
\text { Drying } \\
\text { Ramp Rate } \\
\left({ }^{\circ} \mathrm{C} / \mathrm{min}\right)\end{array}$ & $\begin{array}{l}\text { Secondary } \\
\text { Hold Time } \\
\text { (min) }\end{array}$ \\
\hline $\begin{array}{c}\text { Low } \\
\text { Moisture }\end{array}$ & -40 & 1.00 & 120 & -15 & 1200 & 30 & 0.15 & 600 \\
\hline $\begin{array}{l}\text { High } \\
\text { Moisture }\end{array}$ & -40 & 1.00 & 120 & -40 & 900 & 15 & 0.18 & 60 \\
\hline
\end{tabular}

\subsection{Diphtheria and Tetanus ELISA}

Anti-diphtheria or anti-tetanus IgG binding activity levels are commonly determined using the ELISA technique as an alternative to in vivo toxin neutralization tests [18]. In brief, 96-well plates were coated with either diphtheria toxoid (NIBSC product code 13/212) or tetanus toxoid (NIBSC product code $02 / 126$ ) as coating antigen, sealed and left to incubate overnight at $4{ }^{\circ} \mathrm{C}$. The next day plates 
were washed with PBS containing Tween-20 0.05\% v/v (PBST) and then blocked with blocking buffer (PBST $+5 \%$ skimmed milk powder). Plates were incubated at $37^{\circ} \mathrm{C}$ for $1 \mathrm{~h}$ and washed as before. Sample and reference antitoxin dilutions were prepared in sample buffer (PBST $+1 \%$ skimmed milk powder). WHO International Standard antitoxins for diphtheria (NIBSC product code 10/262) and tetanus (NIBSC product code TE-3) were included on each plate to allow specific IgG concentrations to be expressed in IU/mL. A total of $200 \mathrm{~mL}$ of diluted sample or reference were added to the top row of wells and titrated down the plate using a manual multichannel pipette set to $100 \mu \mathrm{L}$. After serial dilutions, plates were once again incubated at $37^{\circ} \mathrm{C}$ for $2 \mathrm{~h}$ and washed as before. Anti-human IgG HRP-conjugate (Sigma A8792, Sigma-Aldrich) was diluted 1/2000 in sample buffer and $100 \mu \mathrm{L}$ was added to each well before incubation at $37^{\circ} \mathrm{C}$ for $1 \mathrm{~h}$. Substrate solution containing citric acid buffer and ABTS (2,2' -Azinobis (3-ethylbenzothiazoline-6-sulfonic acid) diammonium salt) tablets was added to all wells for colour to develop. Absorbance was read at $405 \mathrm{~nm}$ on a Molecular Devices Vmax plate reader running Softmax Pro 6.5.1 (Molecular Devices, Wokingham, UK). Data analysis was performed in CombiStats (version 5.0, 2013, EDQM, Strasbourg, France).

\subsection{SEC-HPLC}

Size-exclusion high performance liquid chromatography (SEC-HPLC) is a commonly applied chromatographic method used for determining of aggregation or monomer content of biotherapeutic proteins in solutions via size or molecular weight differences [19]. SEC-HPLC was used to determine the monomer content of the FD IgG samples after reconstitution. Analysis was performed using the Thermo Scientific UltiMate 3000 HPLC System (Thermo Fisher Scientific, Loughborough, UK) with a TSKgel G3000SWXL HPLC column $(300 \times 7.8 \mathrm{~mm}$, Sigma-Aldrich). Ultraviolet (UV) detection was measured at $280 \mathrm{~nm}$ in triplicate $(n=3)$. The mobile phase was prepared from the formula as outlined in European Pharmacopeia 9.0: Human Normal Immunoglobulin for intravenous administration (01/2012:0918) [8], consisting of disodium hydrogen phosphate dihydrate $(0.49 \% w / v)$, sodium dihydrogen phosphate monohydrate $(0.17 \% w / v)$, sodium chloride $(1.17 \% w / v)$ and sodium azide $(0.01 \% w / v)$. The flow-rate on the apparatus was set at $0.5 \mathrm{~mL} / \mathrm{min}$. Peak analysis was performed using Chromeleon 7.2SR software (Thermo Fisher Scientific, Loughborough, UK).

\subsection{Residual Moisture Content}

The moisture content of the FD cakes within the vials was measured using an automated coulometric Karl Fischer instrument (Mitsubishi CA-200, A1-Envirosciences Ltd., Blyth, UK). Samples were transferred into HPLC autosampler vials within a pyramid dry bag (Captair pyramid, 2200A Cole Palmer, London, UK). Nitrogen gas was used to purge the pyramid air bag to ensure that a humidity < $5 \%$ RH was achieved. All samples were tested in triplicates $(n=3)$, i.e., 3 vials were tested.

\section{Results and Discussion}

\subsection{Case Study 1: Effect of Moisture Ingress and Excipient Ratio on Storage Stability of High Concentration IgG}

Polyclonal human immunoglobulin is derived from many thousands of donors from the population, and so a dimer content of between $8 \%$ and $10 \%$ can occur naturally and is of itself not an indicator of aggregation [20]. Usually a protein-to-sugar weight ratio of 1:1 would be suitable for optimal stabilisation. However, in this study the IgG molar/weight ratio was intentionally varied as the sucrose excipient concentration of $10 \mathrm{mg} / \mathrm{mL}(1 \% w / w)$ was maintained in order to investigate the destabilizing effect of moisture ingress and/or storage temperature conditions during long-term storage. As such the sucrose:protein molar ratio for these investigations were as follows: $1 \%$ sucrose to $1 \% \operatorname{IgG}$ is $439: 1 ; 5 \%$ IgG is $88: 1 ; 10 \% \operatorname{IgG}$ is $44: 1$; and $20 \% \operatorname{IgG}$ is $22: 1$. The moisture content before and after 12 months storage is displayed in Figure 1. 

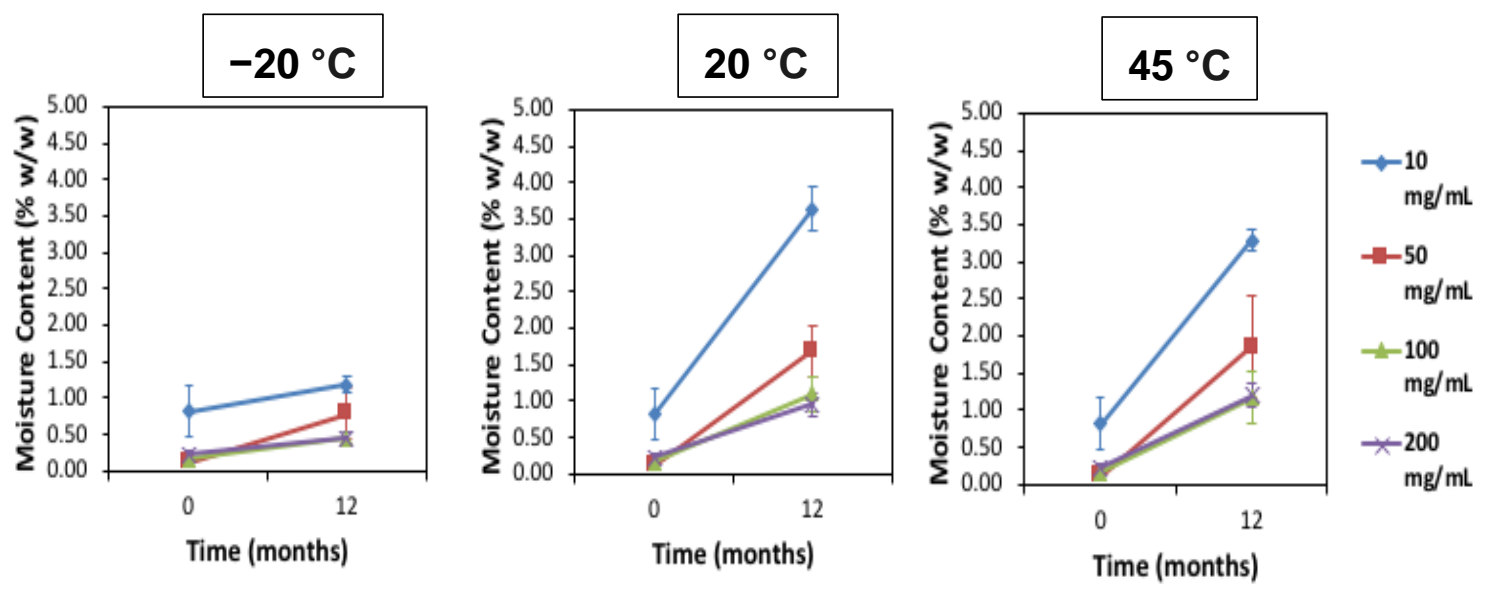

Figure 1. Average moisture content (\%) for low to high concentration freeze-dried (FD) IgG before and after 12 months of storage at $-20,20$ and $45^{\circ} \mathrm{C}$. Error bars are $95 \%$ confidence intervals $(n=3$ vial replicates).

After 12 months of storage, for all IgG concentrations there was an increase in moisture content, especially at the higher storage temperatures of $20^{\circ} \mathrm{C}$ and $45^{\circ} \mathrm{C}$. The $10 \mathrm{mg} / \mathrm{mL}$ samples had the highest moisture ingress at $20^{\circ} \mathrm{C}$ and $45{ }^{\circ} \mathrm{C}$ at around $3-4 \% w / w$ moisture content $(n=3)$. With increasing IgG concentration there was less moisture uptake at these elevated temperatures of between $1 \%$ and $2 \% w / w$ moisture. The most common sources of moisture ingress are likely due to either trapped moisture in the headspace of the vials or moisture actually emanating from the rubber stoppers [14,21]. Past studies and research have shown the negative consequences of elevated moisture and temperature on FD biologics stability and structure [22,23]. Increasing moisture content can lead to a reduction of the $T_{g}$ due to the its plasticizing effect $[24,25]$. Table 2 shows the $T_{g}$ of the IgG after 12 months of storage as measured with DSC $(n=2)$. The difference between storage temperature and the $\mathrm{T}_{\mathrm{g}}$ (denoted as $\mathrm{T}_{\mathrm{g}}-\mathrm{T}$ ) is largest at the lowest temperature of $-20^{\circ} \mathrm{C}$ storage and becomes smaller as the storage temperature is increased through $20^{\circ} \mathrm{C}$ to $45^{\circ} \mathrm{C}$.

Table 2. Comparison of difference in storage temperature $\mathbf{T}$ and glass transition temperature $\mathbf{T}_{\mathbf{g}}$ after 12 months of storage.

\begin{tabular}{cccc}
\hline Storage Temperature $\left({ }^{\circ} \mathbf{C}\right)$ & IgG Concentration $(\mathbf{m g} / \mathbf{m L})$ & $\mathbf{T}_{\mathbf{g}}$ & $\mathbf{T}_{\mathbf{g}}-\mathbf{T}\left({ }^{\circ} \mathbf{C}\right)$ \\
\hline-20 & 10 & 101 & 121 \\
-20 & 50 & 104 & 124 \\
-20 & 100 & 110 & 130 \\
-20 & 200 & 105 & 125 \\
\hline 20 & 10 & 94 & 74 \\
20 & 50 & 96 & 76 \\
20 & 100 & 117 & 97 \\
20 & 200 & 116 & 96 \\
45 & 10 & 77 & 32 \\
45 & 50 & 84 & 39 \\
45 & 100 & 84 & 39 \\
45 & 200 & 90 & 45 \\
\hline
\end{tabular}

The impact of the storage conditions and moisture on the monomeric (\%) content and binding activity of the IgG are shown in Figures 2 and 3. Storage at $-20{ }^{\circ} \mathrm{C}$ showed that there was minimal monomeric loss (less than $1 \%$ ) for IgG at all concentrations. Increasing temperature resulted in greater loss of monomer and higher IgG concentrations suffered greater losses in monomer, especially at $45^{\circ} \mathrm{C}$. The order from least monomer loss to highest at $45^{\circ} \mathrm{C}$ storage was $10 \mathrm{mg} / \mathrm{mL}<50 \mathrm{mg} / \mathrm{mL}<100 \mathrm{mg} / \mathrm{mL}$ $<200 \mathrm{mg} / \mathrm{mL}$. The binding activity (IU/mL normalised into IU/mg) was measured by ELISA for specific 
IgG (anti-diphtheria andante- tetanus) over the course of the 12-month storage. Anti-tetanus and anti-diphtheria antibodies were chosen as markers for specific IgG since the majority of donors used in production of the IgG products will have received diphtheria and tetanus immunisation as part of routine immunisation programmes. It is interesting to note that while the monomer content was decreasing throughout storage at elevated temperature, the binding activity remained relatively stable until the last time point $(\mathrm{T}=12)$ and only for the 50 and $100 \mathrm{mg} / \mathrm{mL}$ samples. It is important to note that the specific antibodies being measured here represent only a small proportion of the total IgG in the formulation. However, for the $200 \mathrm{mg} / \mathrm{mL}$ samples there was high variability in activity, due to fact that the $200 \mathrm{mg} / \mathrm{mL}$ samples did not fully reconstitute, thus giving variable ELISA results.
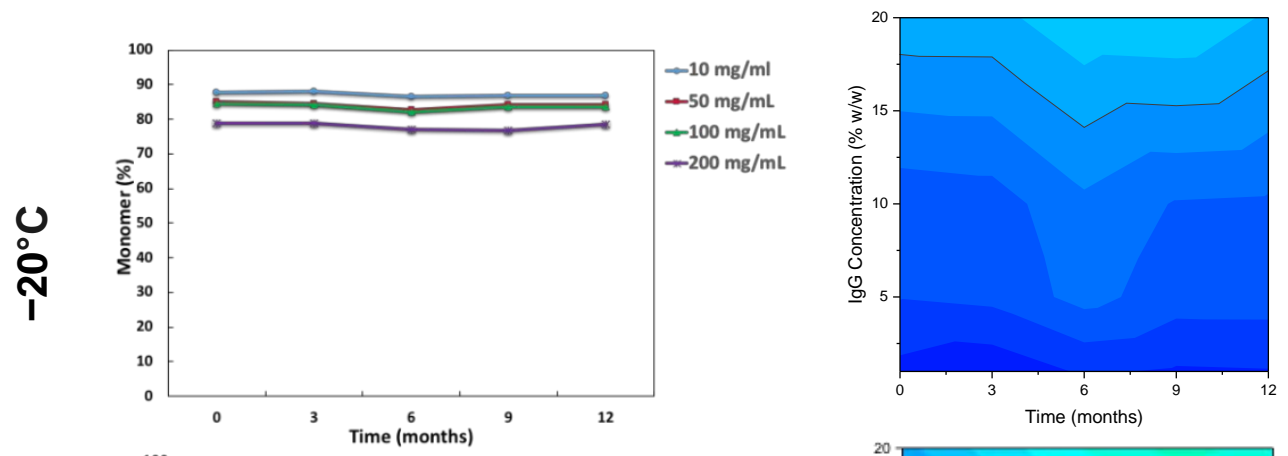

Monomer (\%)
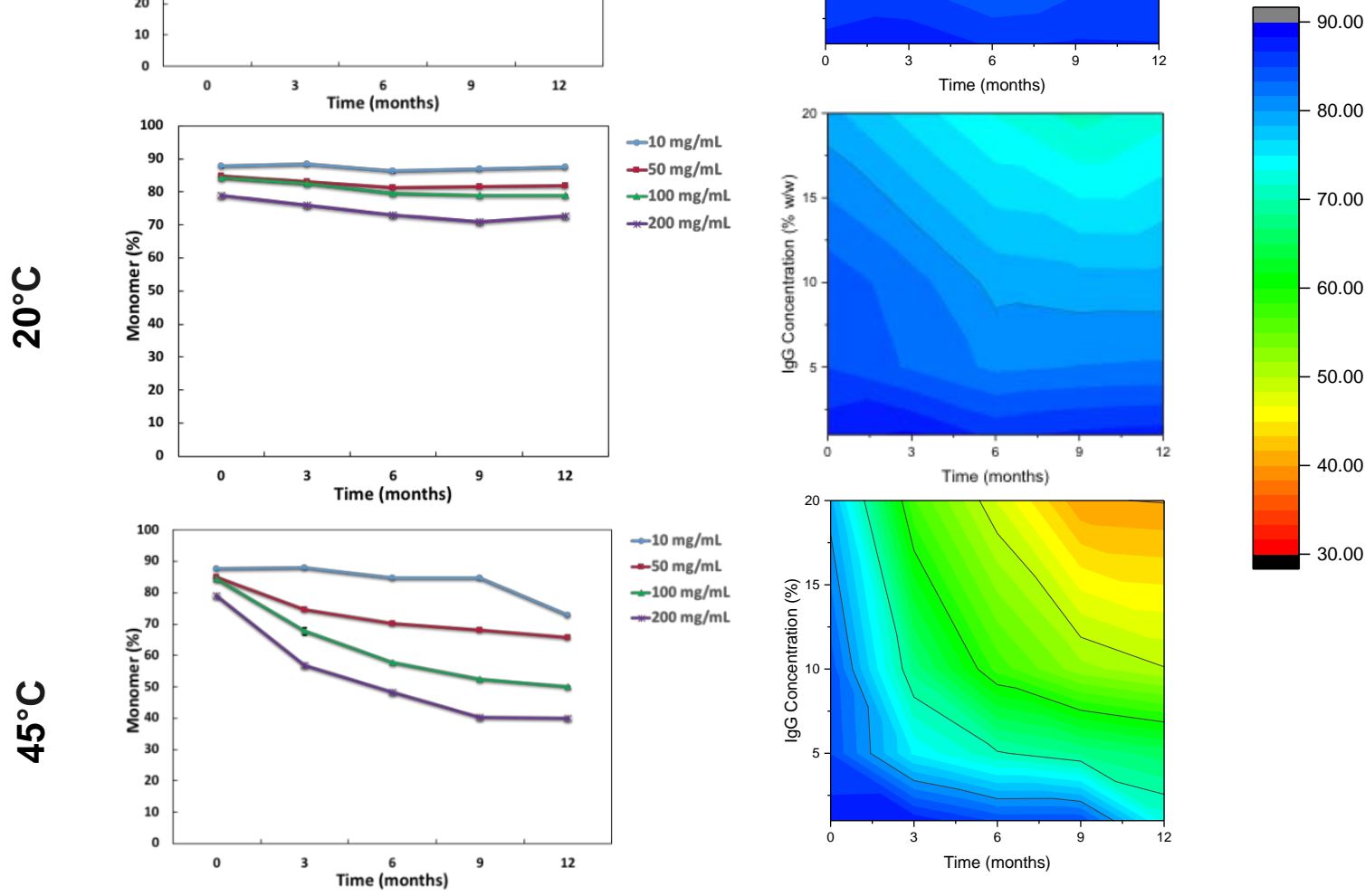

Figure 2. Average monomer content (\%) over time for low to high concentration IgG with contour stability maps as measured by SEC-HPLC over 12 months stored at (from top to bottom) $-20{ }^{\circ} \mathrm{C}, 20^{\circ} \mathrm{C}$ and $45^{\circ} \mathrm{C}$ ( $n=3$ vial replicates). Error bars at $95 \%$ confidence intervals are too small to be seen. 

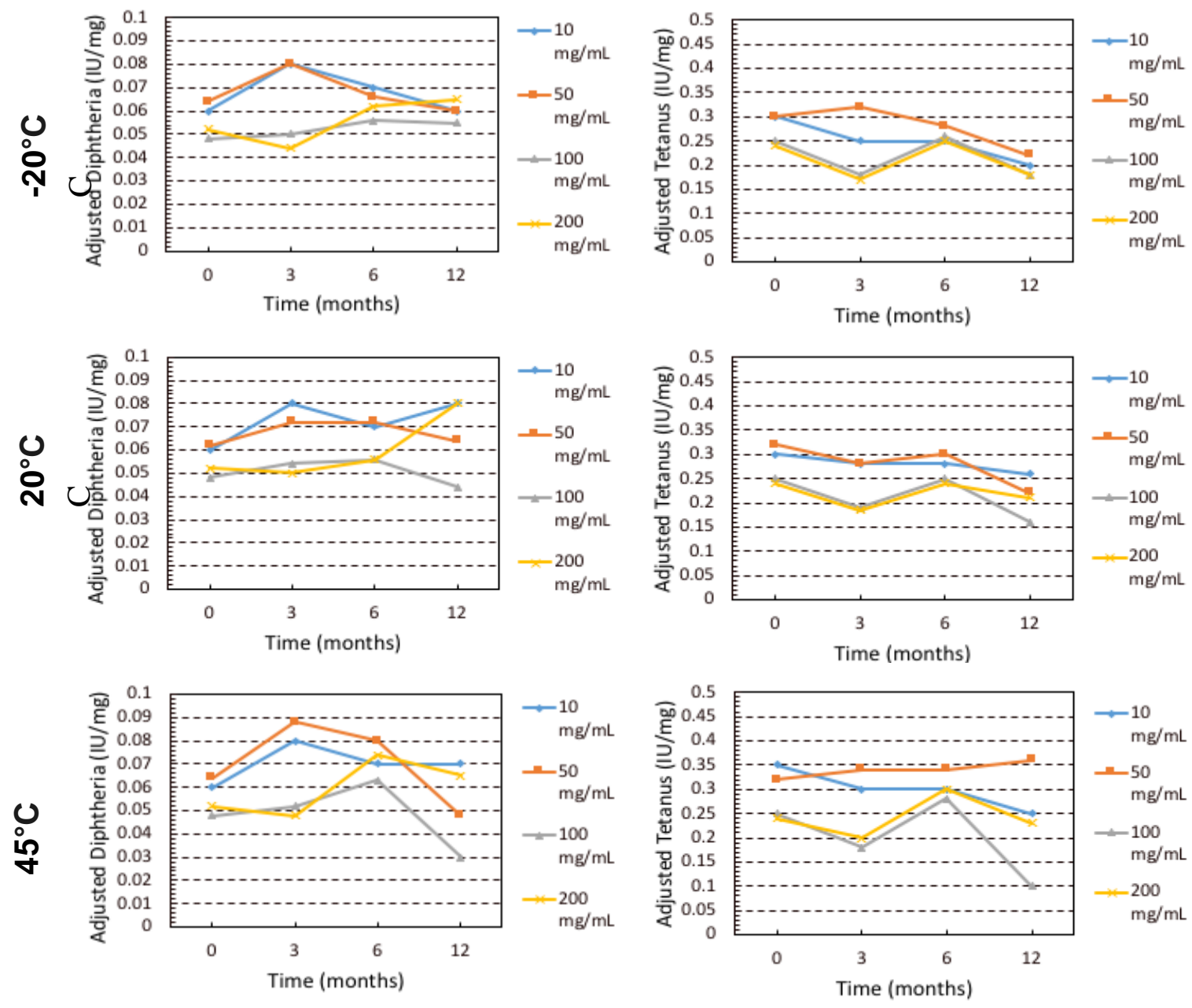

Figure 3. ELISA Diphtheria and Tetanus normalized binding activity (IU/mg) for IgG over the course of 12 months stored at $-20^{\circ} \mathrm{C}, 20^{\circ} \mathrm{C}$ and $45^{\circ} \mathrm{C}$.

The 10, 50 and $100 \mathrm{mg} / \mathrm{mL}$ IgG had a clear visual appearance after being fully reconstituted. However, the $200 \mathrm{mg} / \mathrm{mL}$ samples stored at $45^{\circ} \mathrm{C}$ were slightly cloudy/viscous with tiny clumps of particulates still undissolved (Figure 4). In addition, on average the $10-50 \mathrm{mg} / \mathrm{mL}$ samples took up to $5 \mathrm{~min}$ to reconstitute while the $200 \mathrm{mg} / \mathrm{mL}$ samples took over $2 \mathrm{~h}$ to dissolve. Long reconstitution times have been commonly reported for high concentration protein solutions [26,27], and strategies for addressing this have been shared [7].

The results presented in this study are slightly unusual in that the highest concentration protein was shown to be the least stable. These results are counter to the general trend expecting higher concentrations tending to be more stable. It is possible that at these very high concentrations of FD IgG they are more temperature labile compared to lower concentrations due to a lack of excipient protection from the formulation, as the ratio of IgG:sucrose falls from 400:1 to 22:1. Table 2 shows that the $10 \mathrm{mg} / \mathrm{mL} \operatorname{IgG}$ had a smaller difference $\left(\mathrm{T}_{\mathrm{g}}-\mathrm{T}\right)$ value than for the higher concentrations, yet demonstrated lower monomer loss at $45^{\circ} \mathrm{C}$. Even though the lowest concentration $\operatorname{IgG}$ had the highest moisture content and reduced $\mathrm{T}_{\mathrm{g}}$, it was shielded because it had a higher excipient-to-protein ratio protection while the higher concentration did not, thus supporting a case for water replacement theory. However, the moisture content was similar at both $20^{\circ} \mathrm{C}$ and $45{ }^{\circ} \mathrm{C}$, yet the largest drops were only observed at $45^{\circ} \mathrm{C}$ for samples of $50-200 \mathrm{mg} / \mathrm{mL}$. One possible explanation for this is that of the $\mathrm{T}_{\mathrm{g}}$ being closer to the high storage temperature and hence increasing molecular flexibility—supporting a role for the glass dynamics hypothesis $\left(\mathrm{T}_{\mathrm{g}}-\mathrm{T}\right)$. The question of optimum moisture content and mechanisms of stabilization (be it water substitution theory or glass vitrification hypothesis) has been a matter of 
debate [28]. These results provide a case for both water replacement theory and vitrification hypothesis in terms of stabilization. Overall, moisture ingress during storage (from as high as $1 \%$ to $4 \% w / w$ ) occurs for all FD IgG concentrations up to $200 \mathrm{mg} / \mathrm{mL}$ and needs to be considered, although for these high concentration proteins the moisture appeared to have minimal impact on the stability at $-20{ }^{\circ} \mathrm{C}$ and $20^{\circ} \mathrm{C}$.

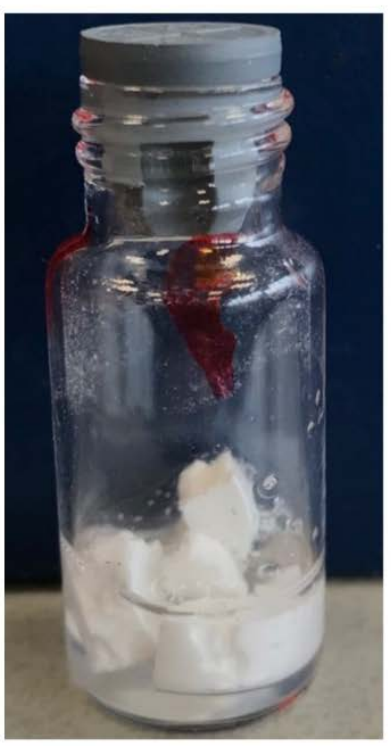

$0 \mathrm{~min}$

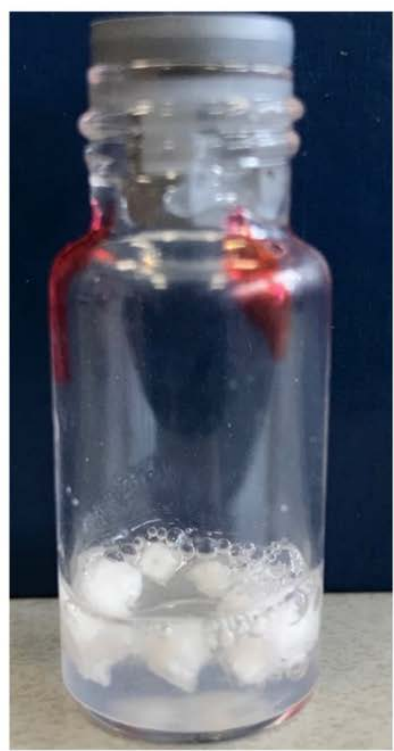

$60 \mathrm{~min}$

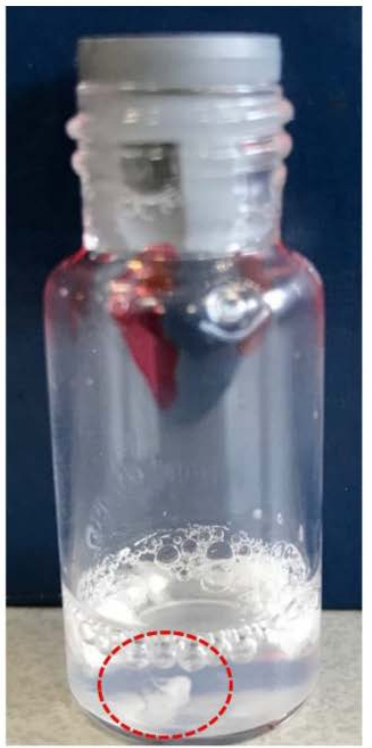

$120 \mathrm{~min}$

Figure 4. Visual appearance of $\operatorname{IgG} 200 \mathrm{mg} / \mathrm{mL}$ dissolved in water up to 0,60 and $120 \mathrm{~min}$ for the $\mathrm{T}=12$-month-old sample aged at $45^{\circ} \mathrm{C}$.

\subsection{Case Study 2: Optimum Moisture Content of IgG}

The second investigation considered the acceptable "moderate" moisture content of FD IgG at $50 \mathrm{mg} / \mathrm{mL}$ over the course of a 6 months stability study. Samples were all prepared initially in a low moisture cycle producing moisture contents of $0.05 \% \pm 0.01 \% w / w(n=3)$, (A). Vials were exposed to the humid room atmosphere at several different time intervals of 30,90 and $180 \mathrm{~min}$, respectively $(57 \% \mathrm{RH}$ at temperature of $20^{\circ} \mathrm{C}$ ). The increased moisture contents before storage were measured as (B) $0.67 \% \pm$ $0.14 \% w / w,(C) 3.02 \% \pm 0.06 \% \mathrm{w} / \mathrm{w}$ and (D) $4.95 \% \pm 0.40 \% w / w(n=3)$. Figure 5 shows the moisture ingress over 6 months from different initial starting moisture contents. All samples showed constant moisture content at $-20^{\circ} \mathrm{C}$; however, the drier the sample had started out then the more moisture ingress was observed after 6 months at elevated storage temperatures. Sample A (with the lowest initial moisture content) had a significant increase in moisture content after 6 months at $20^{\circ} \mathrm{C}$ and $45^{\circ} \mathrm{C}$ up to $1 \% w / w$. For Sample A, this uptake is most likely to reflect moisture transfer from inside the vial stopper. For very low moisture content FD materials, there is a diffusion-driven water migration from the stopper interior to the relatively dry cakes. The other samples have moisture contents within an experimental error of each other and exhibited no similar major moisture ingress. The effect of different moisture content on the monomer content (\%) and binding activity (IU/mL) is shown in Figures 6 and 7. Table 3 shows the comparison between moisture content of samples and the resulting measured $\mathrm{Tg}$. Over the course of 6 months, storage at $-20^{\circ} \mathrm{C}$ to $20^{\circ} \mathrm{C}$ increased the moisture content up to $5 \%$ $w / w$ and had no impact on monomer content or binding activity. However, at $45^{\circ} \mathrm{C}$, just after 6 months storage, the samples with higher moisture (above $1 \% w / w$ moisture) began to see around a $10 \%$ drop in monomer content, whereas for sample A (below $1 \% w / w$ moisture) there is no losses. This is in stark contrast with the binding activity results, which show that at no point is there any loss for all moisture content samples (A-D) up to $5 \% w / w$. One possible explanation for this behaviour is that in the previous case study moisture content ingress naturally increased over time, whilst for this study 
the samples were exposed to atmosphere and hence possible oxygen trapped in headspace. Oxidation might have occurred in this study, which could have led to more protein-protein aggregation.
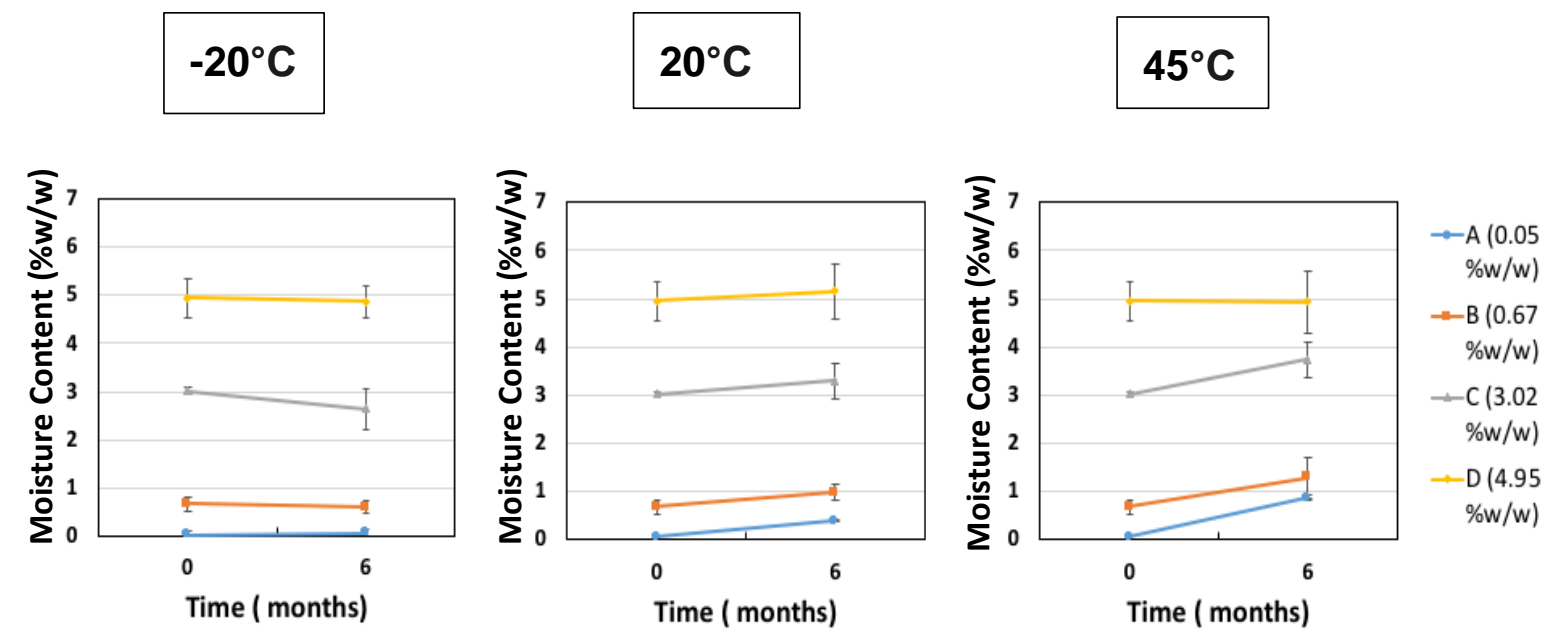

Figure 5. Change in moisture content $(\% w / w)$ after 6 months of storage starting at different initial starting moisture samples of IgG $50 \mathrm{mg} / \mathrm{mL}(\mathrm{A}=0.05 \% \pm 0.01 \% w / w, \mathrm{~B}=0.67 \% \pm 0.14 \% w / w, \mathrm{C}=3.02 \%$ $\pm 0.06 \% w / w$ and $\mathrm{D}=4.95 \% \pm 0.40 \% w / w)$ at $-20{ }^{\circ} \mathrm{C}, 20{ }^{\circ} \mathrm{C}$ and $45{ }^{\circ} \mathrm{C}$. Error bars represent $95 \%$ confidence intervals ( $n=3$ vial replicates).

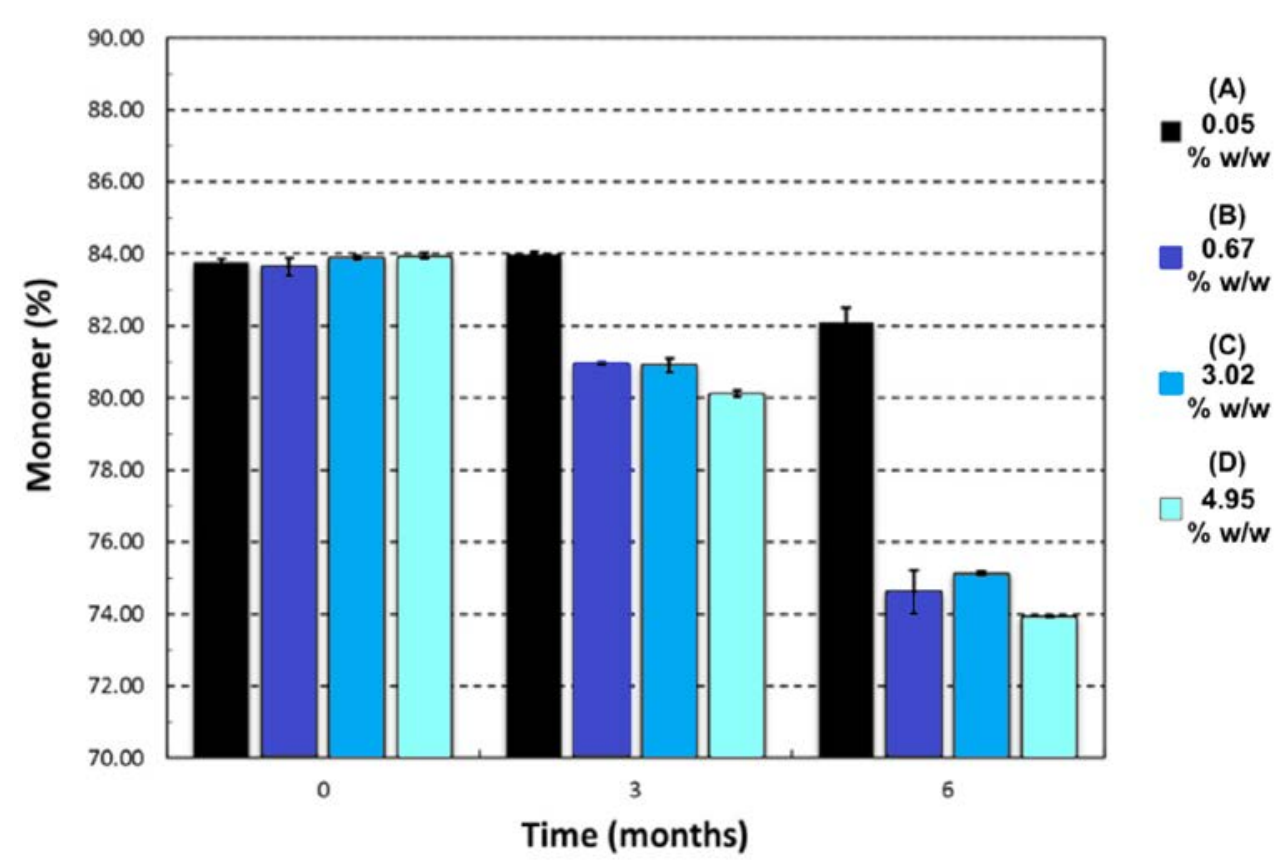

Figure 6. Change in monomer (\%) after 6 months of storage at $45{ }^{\circ} \mathrm{C}$ for different initial moisture samples of IgG $50 \mathrm{mg} / \mathrm{mL}(\mathrm{A}=0.05 \% \pm 0.01 \% w / w, \mathrm{~B}=0.67 \% \pm 0.14 \% w / w, \mathrm{C}=3.02 \% \pm 0.06 \% w / w$ and $\mathrm{D}=4.95 \% \pm 0.40 \% \mathrm{w} / \mathrm{w}$ ). Monomer content was stable for -20 and $20{ }^{\circ} \mathrm{C}$ at $84.0 \% \pm 0.5 \%$ Error bars represent $95 \%$ confidence intervals ( $n=3$ vial replicates). 

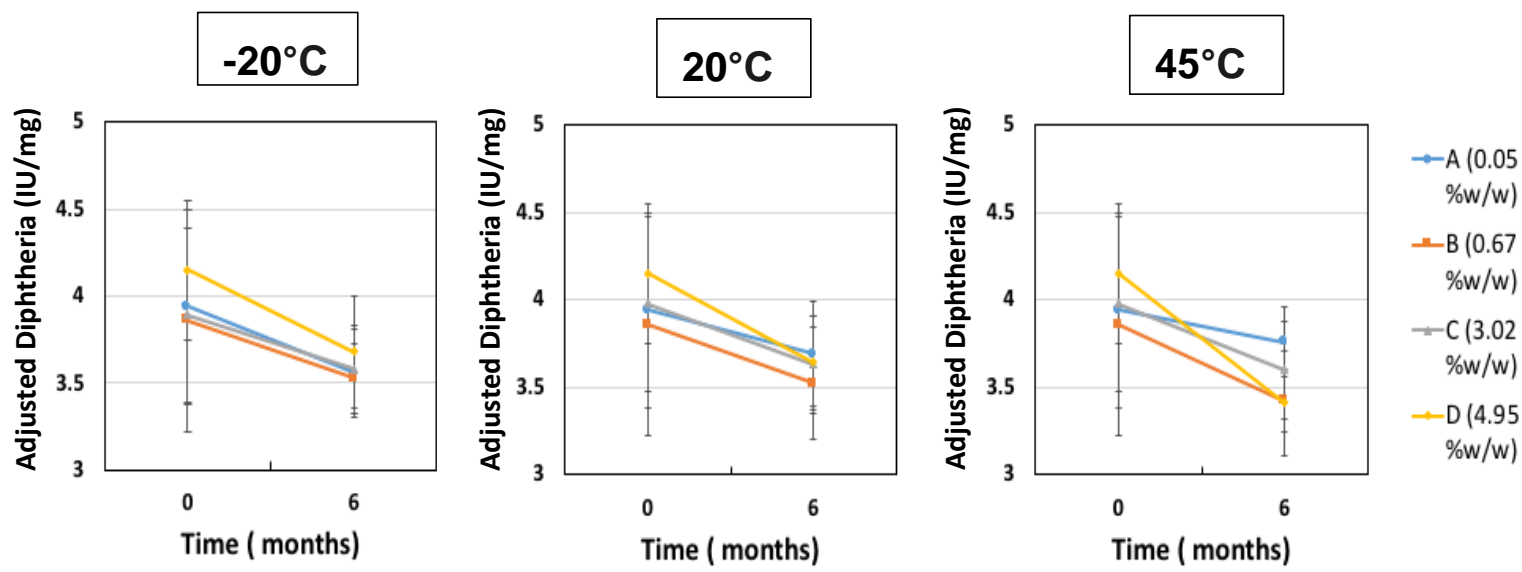

Figure 7. ELISA Diphtheria binding activity $(\mathrm{IU} / \mathrm{mL})$ after 6 months of storage for different initial moisture samples of FD IgG $50 \mathrm{mg} / \mathrm{mL}(\mathrm{A}=0.05 \% \pm 0.01 \% w / w, \mathrm{~B}=0.67 \% \pm 0.14 \% w / w, \mathrm{C}=3.02 \%$ $\pm 0.06 \% w / w$ and $\mathrm{D}=4.95 \% \pm 0.40 \% w / w)$ at $-20{ }^{\circ} \mathrm{C}, 20{ }^{\circ} \mathrm{C}$ and $45{ }^{\circ} \mathrm{C}$. Error bars represent $95 \%$ confidence intervals.

Table 3. Comparison of difference in storage temperatures and glass transition temperatures after 6 months of storage.

\begin{tabular}{cccc}
\hline Temperature $\left({ }^{\circ} \mathbf{C}\right)$ & Initial Moisture Sample $(\% \boldsymbol{w} / w)$ & $\mathbf{T}_{\mathbf{g}}$ & $\mathbf{T}^{\mathbf{T}} \mathbf{T}_{\mathbf{g}}\left({ }^{\circ} \mathbf{C}\right)$ \\
\hline-20 & $0.05(\mathrm{~A})$ & 115 & 135 \\
& $0.67(\mathrm{~B})$ & 113 & 133 \\
$3.02(\mathrm{C})$ & 113 & 133 \\
& $4.95(\mathrm{D})$ & 111 & 131 \\
\hline 20 & $0.05(\mathrm{~A})$ & 114 & 94 \\
& $0.67(\mathrm{~B})$ & 111 & 91 \\
& $3.02(\mathrm{C})$ & 111 & 91 \\
& $4.95(\mathrm{D})$ & 110 & 90 \\
\hline 45 & $0.05(\mathrm{~A})$ & 112 & 67 \\
& $0.67(\mathrm{~B})$ & 113 & 68 \\
& $3.02(\mathrm{C})$ & 110 & 65 \\
& $4.95(\mathrm{D})$ & 108 & 63 \\
\hline
\end{tabular}

These monomer and binding activity results from the induced exposure moisture seemed to suggest that modest moisture content $(\approx 3 \% w / w)$ was perfectly acceptable for $50 \mathrm{mg} / \mathrm{mL}$ IgG when stored at up to $20^{\circ} \mathrm{C}$. However, from the results in this study there was no Gaussian-shaped distribution in terms of moisture and stability observed. In fact, a more linear correlation with moisture was observed for higher temperature storage, which was more in line with what Pikal et al. had observed in a moisture-based stability study [14]. It is worth noting that Chang et al. in a study on a Mab also reported that there was better stability at 2-3\% moisture content than for drier samples [29]. This supports our finding here that an optimum moisture content exists and should be investigated for each formulation.

\subsection{Case Study 3: Stability of Induced "Low" Versus "High" Moisture FD Cycles}

In Case Study 3, we looked at the effect of FD cycle-induced moisture content between a very low moisture content and a moderately high one for a single $\mathrm{IgG}$ concentration $(50 \mathrm{mg} / \mathrm{mL})$. Residual moisture content is controlled by the shelf temperature used in secondary drying. Post-drying exposure to controlled humidity was used in Case Study 2. Cycle-induced moisture might provide different data results with regard to moisture content. The low moisture cycle produced cakes with $0.11 \% \pm$ $0.01 \% w / w$, while the high moisture cycle produced cakes with $3.02 \% \pm 0.8 \% w / w(n=3)$. Previously it has been described that a much higher moisture contents $(8 \% \mathrm{w} / \mathrm{w})$ decreased the stability of a MAbs 
dried at a $40 \mathrm{mg} / \mathrm{mL}$ concentration [11]. However, here, more representative moisture contents $(0.1 \%$ $w / w$ for low cycle and $3 \% w / w$ for high cycle) within the acceptable moisture range for intravenous immunoglobulin [8] were engineered by control of the secondary drying temperature conditions. The moisture content changes from the initial starting points over 12 months of storage. The samples from the low moisture cycle batch had an increase to about $1.5 \% w / w$ moisture at $20{ }^{\circ} \mathrm{C}$ and $45^{\circ} \mathrm{C}$ storage. The samples from the high moisture batch, however, exhibited no such moisture ingress across the temperature range. This may illustrate an equilibration of the moisture in the closure and the hygroscopic dry FD product. Matejtschuk et al. [30] had observed similar equilibrating moisture effects in vials in a study with a model HSA formulation. Once again, a moisture increase over time is seen for vials at or above $20^{\circ} \mathrm{C}$, especially for FD samples that initially had a very low moisture content. It was most likely that a significant portion of moisture ingress could be arising from the stoppers themselves (Figure 8). Stopper drying has been effectively used in the past to maintain a low moisture content during storage [31], and can help reduce water ingress and potential degradation at higher storage temperatures.

\section{$-20^{\circ} \mathrm{C}$}

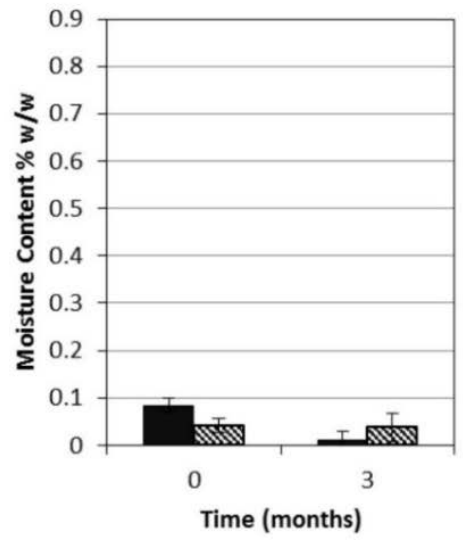

\section{$45^{\circ} \mathrm{C}$}

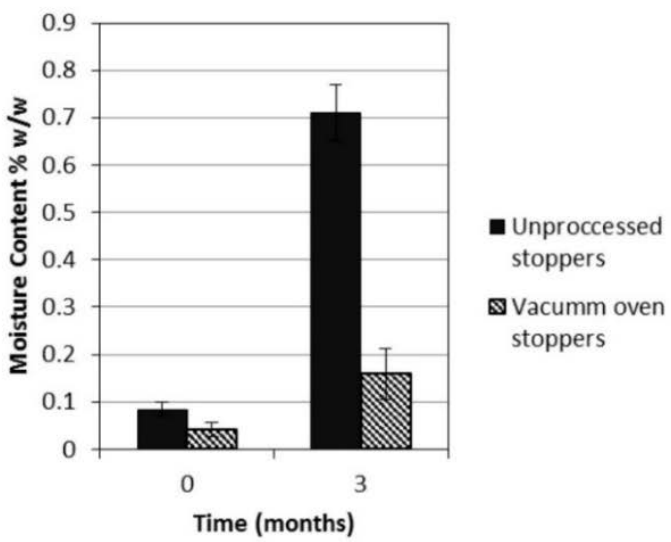

Figure 8. Difference in moisture content for FD IgG $(50 \mathrm{mg} / \mathrm{mL})$ between vials with vacuum-oven-dried stoppers and vials with untreated stoppers straight out of packaging after 3 months of storage at $-20{ }^{\circ} \mathrm{C}$ and $45^{\circ} \mathrm{C}$ ( $n=3$ vial replicates).

Figures 9 and 10 shows the binding activity and monomer (\%) content and compared for IgG $(50 \mathrm{mg} / \mathrm{mL})$ at both a high and low moisture content. After 12 months, there is no major difference or drop in monomer content at $-20^{\circ} \mathrm{C}$ and $20^{\circ} \mathrm{C}$ for vials in either a low cycle or high cycle batch moisture content (remains steady above $80 \%$ monomer content). Similarly, the binding activity does not change greatly for either low and high cycle batch vials at $-20{ }^{\circ} \mathrm{C}$ and $20{ }^{\circ} \mathrm{C}$ storage. However, at $45{ }^{\circ} \mathrm{C}$, samples from the low moisture cycle were observed to have a significantly greater drop in monomer content compared to samples from the high moisture cycle batch. This was also seen for the binding activity data, where the low moisture sample vials saw a drop with activity at $45^{\circ} \mathrm{C}$, whereas the high moisture vials did not. This is also in contrast to the previous Case Study 2, where the samples with highest moisture saw greatest monomer drop at elevated temperature of $45^{\circ} \mathrm{C}$. As stated previously, one possible explanation for this is that the vials in this study were stoppered under vacuum and nitrogen gas, while in the other study the vials were exposed to the environment and had oxygen trapped in the headspace. Oxidation might have occurred in the previous case study, which would have induced pathways to lead to more protein-protein aggregation. However, in a previous study we did not observe any detriment in antibody activity on storage from a higher oxygen content in the headspace [32]. This might also be further evidence of over-drying and for water replacement theory with some moisture being essential for the FD cake stability in allowing hydrogen bonds to form. 


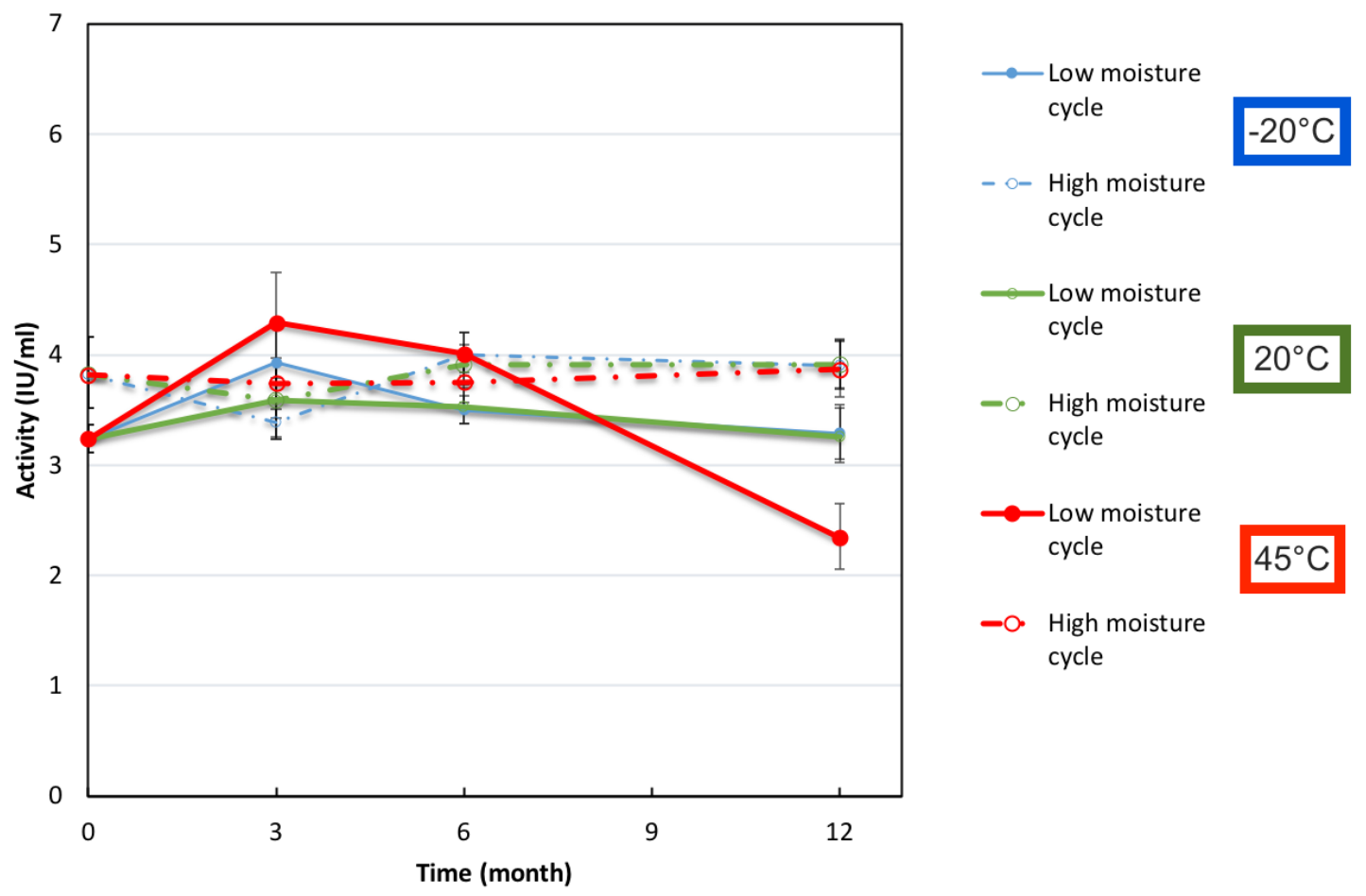

Figure 9. Diphtheria Binding Activity determined by ELISA for FD IgG $50 \mathrm{mg} / \mathrm{mL}$ in "low" or "high" moisture cycle batches over 12 months of storage. Error bars represent $95 \%$ confidence intervals.

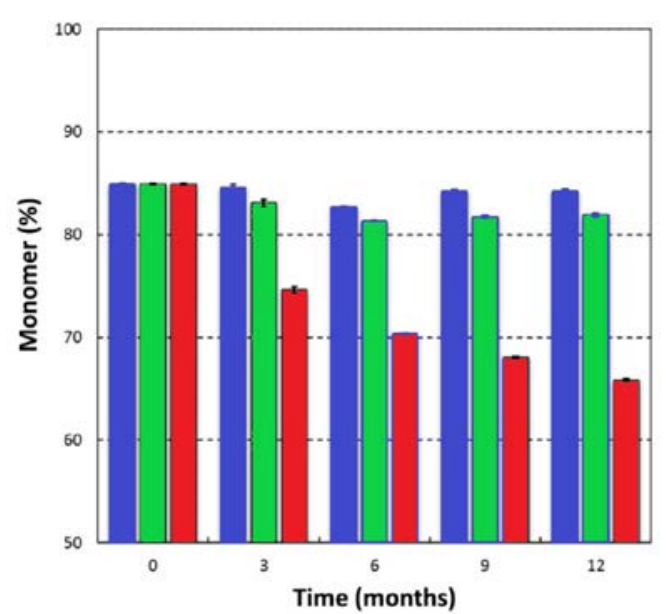

Low Moisture
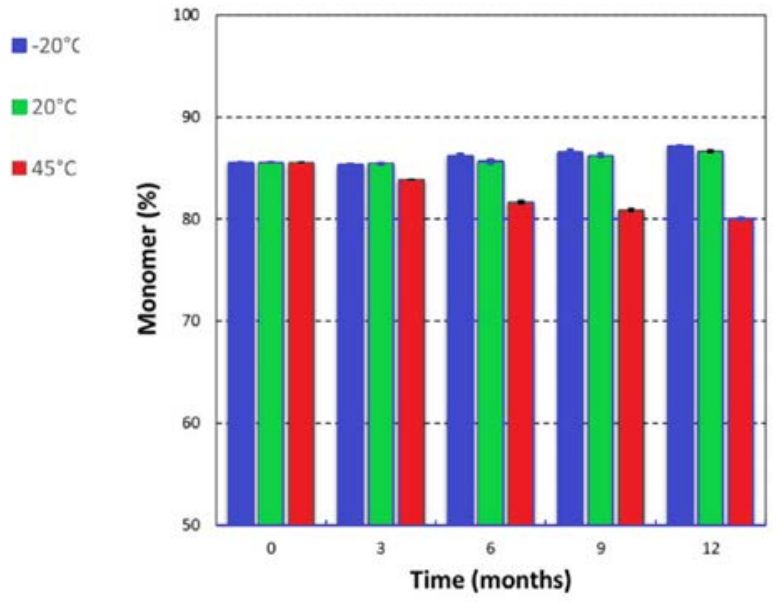

High Moisture

Figure 10. Change in monomer content (\%) of FD IgG $50 \mathrm{mg} / \mathrm{mL}$ vials made under "low" or "high" moisture cycles over 12 months of storage. Error bars represent $95 \%$ confidence intervals $(n=3)$.

Previous reported research from Wang [33], Liu et al. [34] and Greiff [13] have all described an increase in aggregation with higher moisture content (over the optimum level). However, some past studies have also shown that acceptable moisture contents may be permissible in FD cakes without effecting stability [5]. The results here showed evidence that over drying can also have a detrimental effect on stability. In another alternate study, Wang showed for a different formulation that over-drying had greater loss in activity and increased aggregation. Over-drying of FD insulin has also showed to cause damage and increased product degradation [35]. Hubbard et al. noted how a FD reference plasma, with an optimised formulation and a modest moisture content, had greater stability than one with a very low moisture content [36]. These results show some confirmation of the water replacement 
theory. If the FD IgG samples are over dried, the hydrogen bonds are lost between the protein and the water, hence you have a change in conformational structure. Some moisture may be crucial to maintaining the stability of the FD biologics.

These results suggest that in this model system the higher moisture $(3 \% w / w)$ samples are as good as the extremely low moisture samples $(<1 \% w / w)$ and might even show reduced monomer/activity loss at elevated temperatures. Upon visual inspection, there was no colour change between the high and low moisture vials at $-20{ }^{\circ} \mathrm{C}$ and $20{ }^{\circ} \mathrm{C}$ for the entire storage duration. However, at $45^{\circ} \mathrm{C}$ a visible yellow discolouration had appeared on the cakes with the higher moisture content (Figure 11). The discolouration present in the higher moisture batch vials was probably due to Maillard browning (caused by protein free amino group reaction with sugars). Schüle et al. also saw a brown discoloration with lactose in their dried IgG1 stabilization study, which they attributed to Maillard reactions [37]. Kanojia et al. found that after accelerated thermal treatment a chemical modification had occurred in their dry sucrose-dextran IgG formulations, which they too postulated was due to Maillard reaction products [38]. One explanation then might be that there was reducing sugar impurities present in the formulation; however, this is very unlikely due to using a pharmaceutical-grade material. This study also used sucrose in the formulation, which is not a reducing sugar. However, while sucrose is not a reducing sugar, it can break down to fructose and glucose, which are reducing sugars; so, this may explain why this discoloration was only observed for samples stored at higher temperature [39]. Matejtschuk et al. spotted similar discolouration for formulations containing sucrose at elevated storage temperatures [40]. The presence of high moisture content further facilitates these reactions and results in a change in the appearance. It is also a possibility that at the formulated sucrose concentration, buffer crystallisation could have occurred during the freezing, thereby leading to a change to low $\mathrm{pH}$ at which sucrose could have broken down to fructose and glucose [41]. Of course, when it comes to commercialisation, product appearance is a key factor and acceptable and unacceptable product appearance defects have recently been reviewed [42]. Although it may be possible to illustrate that a relatively higher moisture content is beneficial in terms of product stability, the risk of developing a yellow cake appearance on storage would be a drawback for customers as most would be familiar with a white homogeneous product appearance. The potential immunogenicity effects would also need to be addressed.

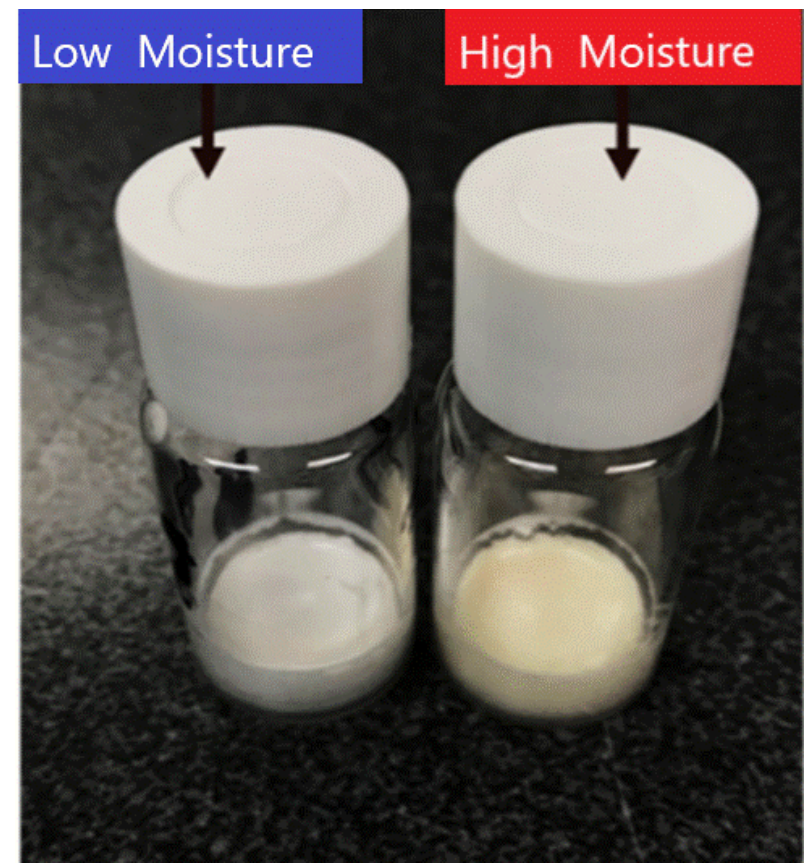

Figure 11. Comparison of the visual appearance between vials FD in either "low" or "high" moisture cycles for FD IgG $(50 \mathrm{mg} / \mathrm{mL})$ after 12 months storage at $45^{\circ} \mathrm{C}$. 


\section{Conclusions}

Freeze-drying can provide excellent long-term stability for high concentration IgG proteins but needs to be considered in the context of factors such as moisture content and intended storage temperature. FD IgG from $10-200 \mathrm{mg} / \mathrm{mL}$ had minimal monomer/activity losses at up to 12 months of storage at $20^{\circ} \mathrm{C}$. IgG $10 \mathrm{mg} / \mathrm{mL}$ with the $1: 1$ protein:sucrose ratio had greater stability shielding at elevated temperatures compared to concentrations above $50 \mathrm{mg} / \mathrm{mL}$, but this may reflect the need for a higher sucrose content at a higher protein composition. There may be an optimum moisture content range for FD IgG, and this needs to be informed with reference to the storage temperature compared to the glass transition temperature. From $-20{ }^{\circ} \mathrm{C}$ to $20^{\circ} \mathrm{C}$ moisture content up to $5 \% w / w$ does not seem to have any impact on monomer or binding activity during prolonged storage. It is only at elevated temperatures, such as at $45^{\circ} \mathrm{C}$ storage, that high moisture seemed to affect the monomer for IgG at $50 \mathrm{mg} / \mathrm{mL}$, although this might be because of oxygen ingress during the exposure trial study. In the comparison between "high" versus "low" FD cycle-prepared materials the opposite was seen, in that the higher moisture content vials performed better at $45^{\circ} \mathrm{C}$ than the extremely dry moisture samples. While some moisture content might be permissible and in fact even beneficial, Maillard reactions can occur (discolouration), which could affect commercial prospects for high moisture content samples aged at $45^{\circ} \mathrm{C}$. Moisture ingress into the FD cakes was observed to occur in every trial reported here, and is especially the case for drier samples and at more elevated storage temperatures, although one potential way of counteracting this effect could be by vacuum heat treating the rubber stoppers [31].

Author Contributions: The studies were devised by A.D. in conjunction with D.R.W. and P.M. with input from P.S. on biological assays. The practical laboratory work was performed by A.D. and in terms of the biological activity assays in cooperation with R.T. and L.H. Data analysis and interpretation involved all authors. The manuscript was written by A.D. and developed and revised in conjunction with P.S., D.R.W. and P.M. All authors have read and agreed to the published version of the manuscript.

Funding: This work was funded by a PhD grant from Engineering and Physical Sciences Research Council (EPSRC) Centre for Doctoral Training in Emergent Macromolecular Therapies, Department of Biochemical Engineering, at University College London to DRW to cover AD's PhD studies.

Acknowledgments: The research was performed at Imperial College Department of Chemical Engineering in collaboration with National Institute for Biological Standards and Control (NIBSC, UK). We also thank the Bacteriology Division (NIBSC, UK) for ELISA testing assistance and Kiran Malik, Chinwe Duru and Ernest Ezeajughi (Standardisation Science) for providing training in some of the analytical techniques.

Conflicts of Interest: The authors declare no conflicts of interest.

\section{References}

1. Shire, S.J.; Shahrokh, Z.; Liu, J. Challenges in the development of high protein concentration formulations. J. Pharm. Sci. 2004, 93, 1390-1402. [CrossRef] [PubMed]

2. Warne, N.W. Development of high concentration protein biopharmaceuticals: The use of platform approaches in formulation development. Eur. J. Pharm. Biopharm. 2011, 78, 208-212. [CrossRef] [PubMed]

3. Garidel, P.; Presser, I. Lyophilization of High.-Concentration Protein Formulations. In Lyophilization of Pharmaceuticals and Biologicals: New Technologies and Approaches; Ward, K.R., Matejtschuk, P., Eds.; Springer Press: New York, NY, USA, 2019; pp. 291-325.

4. Costantino, H.R. Excipients for Use in Lyophilized Pharmaceutical Peptides \& Proteins. In Lyophilization of Biopharmaceuticals; Costantino, H.R., Pikal, M.J., Eds.; AAPS Press: Arlington, TX, USA, 2004; p. 139.

5. Wang, W. Lyophilization and development of solid protein pharmaceuticals. Int. J. Pharm. 2000, 203, 1-60. [CrossRef]

6. Beech, K.E.; Biddlecombe, J.G.; Van Der Walle, C.F.; Stevens, L.A.; Rigby, S.P.; Burley, J.C.; Allen, S. Insights into the influence of the cooling profile on the reconstitution times of amorphous lyophilized protein formulations. Eur. J. Pharm. Biopharm. 2015, 96, 247-254. [CrossRef]

7. Cao, W.; Krishnan, S.; Ricci, M.S.; Shih, L.-Y.; Liu, D.; Gu, J.H.; Jameel, F. Rational design of lyophilized high concentration protein formulations-mitigating the challenge of slow reconstitution with multidisciplinary strategies. Eur. J. Pharm. Biopharm. 2013, 85, 287-293. [CrossRef] 
8. European Pharmacopoeia Commission. European Pharmacopoeia, 9th ed.; EDQM: Strasbourg, France, 2017.

9. Wasserman, R.L. Gammaplex®5 and $10 \%$ in the treatment of primary immunodeficiency and chronic immune thrombocytopenic purpura. Immunotherapy 2017, 9, 1071-1088. [CrossRef]

10. Chaigne, B.; Mouthon, L. Mechanisms of action of intravenous immunoglobulin. Transfus. Apher. Sci. 2017, 56, 45-49. [CrossRef]

11. Breen, E.D.; Curley, J.G.; Overcashier, D.E.; Hsu, C.C.; Shire, S.J. Effect of moisture on the stability of a lyophilized humanized monoclonal antibody formulation. Pharm. Res. 2001, 18, 1345-1353. [CrossRef]

12. Hsu, C.C.; Ward, C.A.; Pearlman, R.; Nguyen, H.M.; Yeung, D.A.; Curley, J.G. Determining the optimum residual moisture in lyophilized protein pharmaceuticals. Dev. Boil. Stand. 1992, 74, 255-270.

13. Greiff, D. Protein structure and freeze-drying: The effects of residual moisture and gases. Cryobiol. 1971, 8, 145-152. [CrossRef]

14. Pikal, M.J.; Shah, S. Moisture transfer from stopper to product and resulting stability implications. Dev. Boil. Stand. 1992, 74, 165-177.

15. Haider, S.; Ashok, A. ICH Harmonised Tripartite Guideline. In Biotechnology: A Comprehensive Training Guide for the Biotechnology industry; CRC Press Inc.: Boca Raton, FL, USA, 2009; pp. 541-555.

16. Tamizi, E.; Jouyban, A. Forced degradation studies of biopharmaceuticals: Selection of stress conditions. Eur. J. Pharm. Biopharm. 2016, 98, 26-46. [CrossRef] [PubMed]

17. Halley, J.; Chou, Y.R.; Cicchino, C.; Huang, M.; Sharma, V.; Tan, N.C.; Thakkar, S.; Zhou, L.L.; Al-Azzam, W.; Cornen, S.; et al. An Industry Perspective on Forced Degradation Studies of Biopharmaceuticals: Survey Outcome and Recommendations. J. Pharm. Sci. 2020, 109, 6-21. [CrossRef]

18. Van Hoeven, K.H.; Dale, C.; Foster, P.; Body, B. Comparison of Three Enzyme-Linked Immunosorbent Assays for Detection of Immunoglobulin G Antibodies to Tetanus Toxoid with Reference Standards and the Impact on Clinical Practice. Clin. Vaccine Immunol. 2008, 15, 1751-1754. [CrossRef] [PubMed]

19. Hong, P.; Koza, S.; Bouvier, E.S.P. A Review Size Exclusion Chromatography for the Analysis of Protein Biotherapeutics and their Aggregates. J. Liq. Chromatogr. Relat. Technol. 2012, 35, 2923-2950. [CrossRef] [PubMed]

20. Tankersley, D.L.; Preston, M.; Finlayson, J. Immunoglobulin G dimer: An idiotype-anti-idiotype complex. Mol. Immunol. 1988, 25, 41-48. [CrossRef]

21. Ford, A.W.; Dawson, P.J. Effect of Type of Container, Storage Temperature and Humidity on the Biological Activity of Freeze-dried Alkaline Phosphatase. Biologicals 1994, 22, 191-197. [CrossRef]

22. Duralliu, A.; Matejtschuk, P.; Williams, D.R. Measuring the specific surface area (SSA) of freeze-dried biologics using inverse gas chromatography. Eur. J. Pharm. Biopharm. 2019, 142, 216-221. [CrossRef]

23. Franks, F. Long-Term Stabilization of Biologicals. BioTechnology 1994, 12, 253-256. [CrossRef]

24. Her, L.; Nail, S.L. Measurement of Glass Transition Temperatures of Freeze-Concentrated Solutes by Differential Scanning Calorimetry. Pharm. Res. 1994, 11, 54-59. [CrossRef]

25. Shamblin, S.L.; Zografi, G. The effects of absorbed water on the properties of amorphous mixtures containing sucrose. Pharm. Res. 1999, 16, 1119-1124. [CrossRef] [PubMed]

26. Garidel, P.; Pevestorf, B.; Bahrenburg, S. Stability of buffer-free freeze-dried formulations: A feasibility study of a monoclonal antibody at high protein concentrations. Eur. J. Pharm. Biopharm. 2015, 97, 125-139. [CrossRef] [PubMed]

27. Garidel, P.; Kuhn, A.B.; Schäfer, L.V.; Karow-Zwick, A.R.; Blech, M. High-concentration proteins-How high is high? Eur. J. Pharm. Biopharm. 2017, 119, 353-360. [CrossRef] [PubMed]

28. Cicerone, M.T.; Pikal, M.J.; Qian, K.K. Stabilization of proteins in solid form. Adv. Drug Deliv. Rev. 2015, 93, 14-24. [CrossRef] [PubMed]

29. Chang, L.; Shepherd, D.; Sun, J.; Tang, X.; Pikal, M.J. Effect of sorbitol and residual moisture on the stability of lyophilized antibodies: Implications for the mechanism of protein stabilization in the solid state. J. Pharm. Sci. 2005, 94, 1445-1455. [CrossRef] [PubMed]

30. Matejtschuk, P.; Rafiq, S.; Johnes, S.; Das, R.G. A comparison of vials with ampoules for the storage of biological reference materials. Biologicals 2005, 33, 63-70. [CrossRef]

31. Duralliu, A.; Matejtschuk, P.; Dubey, S.; Koroma, H.; Gubinelli, F.; Williams, D.R. The influence of the closure format on the storage stability and moisture content of freeze-dried influenza antigen. Vaccine 2019, 37, 4485-4490. [CrossRef] 
32. Ferguson, M.; Wilkinson, D.E.; Heath, A.; Matejtschuk, P. The first international standard for antibodies to HPV 16. Vaccine 2011, 29, 6520-6526. [CrossRef]

33. Wang, D. Formulation characterization, in Freeze Drying. In Lyophilization of Pharmaceutical and Biological Products, 3rd ed.; Rey, L., May, J.C., Eds.; Informa Healthcare: New York, NY, USA, 2010; pp. 245-265.

34. Liu, W.R.; Langer, R.; Klibanov, A.M. Moisture-induced aggregation of lyophilized proteins in the solid state. Biotechnol. Bioeng. 1991, 37, 177-184. [CrossRef]

35. Matejtschuk, P.; Phillips, P.; Andersen, M. Freeze-Drying of Biological Standards. In Lyophilization of Pharmaceutical and Biological Products, 2nd ed.; Rey, L., May, J.C., Eds.; CRC Press Inc.: Boca Raton, FL, USA, 2004; pp. 317-352.

36. Hubbard, A.; Bevan, S.; Matejtschuk, P. Impact of residual moisture and formulation on Factor VIII and Factor V recovery in lyophilized plasma reference materials. Anal. Bioanal. Chem. 2006, 387, 2503-2507. [CrossRef]

37. Schüle, S.; Schulzfademrecht, T.; Garidel, P.; Bechtoldpeters, K.; Frieß, W. Stabilization of IgG1 in spray-dried powders for inhalation. Eur. J. Pharm. Biopharm. 2008, 69, 793-807. [CrossRef] [PubMed]

38. Kanojia, G.; Have, R.T.; Bakker, A.; Wagner, K.; Frijlink, H.W.; Kersten, G.F.A.; Amorij, J.-P. The Production of a Stable Infliximab Powder: The Evaluation of Spray and Freeze-Drying for Production. PLoS ONE 2016, 11, e0163109. [CrossRef] [PubMed]

39. Eggleston, G.; Vercellotti, J.R. Degradation of Sucrose, Glucose and Fructose in Concentrated Aqueous Solutions Under Constant pH Conditions at Elevated Temperature. J. Carbohydr. Chem. 2000, 19, 1305-1318. [CrossRef]

40. Matejtschuk, P.; Harrison, P.; More, J.E. Dry Heat Treatment of Intravenous Immunoglobulin—Some Practical Considerations. Vox Sang. 1995, 68, 255-257. [CrossRef]

41. Flink, J.M. Nonenzymatic Browning of Freeze-Dried Sucrose. J. Food Sci. 1983, 48, 539-542. [CrossRef]

42. Patel, S.M.; Nail, S.L.; Pikal, M.J.; Geidobler, R.; Winter, G.; Hawe, A.; Davignino, J.; Gupta, S.R. Lyophilized drug product cake appearance: What is acceptable? J. Pharm Sci. 2017, 106, 1706-1721. [CrossRef]

(C) 2020 by the authors. Licensee MDPI, Basel, Switzerland. This article is an open access article distributed under the terms and conditions of the Creative Commons Attribution (CC BY) license (http://creativecommons.org/licenses/by/4.0/). 